\section{The Art of Blasphemy? Interfusions of the Erotic and the Sacred in the Poetry of Donne, Barnes, and Constable}

\section{HELEN HACKETT}

Le rejet de la foi catholique par Donne a, par le passé, été invoqué pour interpréter sa juxtaposition blasphématoire de vocabulaires érotique et religieux. Cet article compare son cas avec celui de deux autres auteurs contemporains dont les blasphèmes peuvent également être interprétés en regard de leurs biographies spirituelles respectives mais contrastées. Barnabe Barnes, le fils d'un évêque anglican, a mis en scène ses tentatives de séduction de son amante, qui consistaient à prier à l'autel de la bienheureuse Vierge Marie. Le cheminement de Henry Constable, pour sa part, du protestantisme vers le catholicisme a également donné lieu dans sa poésie à de provocantes juxtapositions entre le sacré et l'érotisme. Cet article cherche à savoir dans quelle mesure les images catholiques étaient devenues conventionnelles dans la poésie érotique, et à quel moment ces juxtapositions de langage étaient délibérément provocatrices.

striking feature of much English poetry of the 1590s is the use of sacred
imagery in erotic poetry and erotic imagery in sacred poetry, in ways
that seem arresting and unsettling to the modern reader. The sacred imagery
in erotic poetry is often specifically drawn from Catholic practices and doc-
trines - as is notoriously the case in the poetry of John Donne. Ever since
John Carey's landmark book John Donne: Life, Mind and Art (1981), one
way of understanding Donne's use of such imagery has been to place it in
the context of Donne's personal psychobiography: his choice to convert to
Protestant Anglicanism, having been born into a family intensely committed
to Roman Catholicism. Yet Donne was by no means the only 1590s poet to
cross boundaries between the erotic and the sacred and to use Catholic terms
in erotic verse. This essay will consider two of his contemporaries, Barnabe
Barnes and Henry Constable, whose mingling of registers is similarly dis-
turbing to the modern reader. It will explore how far this can be illuminated,
as in Donne's case, by knowledge of their particular religious biographies; Renaissance and Reformation / Renaissance et Réforme, XXVIII, 3 (2004) /27 
what was the valence of Catholic terms and images against the background of Elizabethan state Protestantism; and finally, as we move on into the seventeenth century and Donne becomes a dominant influence over later poets, how Catholic imagery becomes a standard convention of love poetry.

\section{I}

As Arthur Marotti has written, throughout the history of Donne biography "the subjects of Donne's Catholicism and his reactions to it have been a source of trouble and difficulty."1 In the 1980s Carey's John Donne: Life, Mind and Art changed the cartography of Donne criticism, not least by restoring to view the Catholic context of Donne's startling conjunctions of sacred and secular ideas and images. Carey traced Donne's intimate familial connections with Catholic activists and martyrs: his mother's descent from Sir Thomas More; his Jesuit uncle Jasper Heywood's incarceration in the Tower of London; and his brother Henry's death from the plague in Newgate prison, where he was awaiting trial for harbouring a Catholic priest. The priest in question, William Harrington, was hanged, then cut down while still alive, and disembowelled. Carey stressed the ever-present threat of such a fate for Elizabethan Catholics: "Donne was born into a terror." Flynn's 1995 inquiry into Donne's early years, John Donne and the Ancient Catholic Nobility, deepened and added rich detail to our knowledge of the young Donne's connection to and involvement in Catholic networks both in England and abroad. Flynn resoundingly affirmed that this knowledge was essential for a full understanding of Donne's literary work: "We should no more separate study of Donne's life and writings from his and his family's religious persecution and exile than we would separate study of the writings of Solzhenitsyn or Wiesel from theirs."3

The effect of religion on Donne is clear from various writings in which he looked back on his conversion in young adulthood from Catholicism to Anglicanism. In a private letter he described how "I had my first breeding and conversation with men of a suppressed and afflicted Religion, accustomed to the despite of death, and hungry of an imagin'd Martyrdome." 4 In his first print publication, Pseudo-Martyr (1610), he stressed what a strenuous mental and emotional leap conversion had been for him:

I have beene ever kept awake in a meditation of Martyrdome, by being derived from such a stocke and race as, I beleeve, no family, (which is not of farre larger extent, and greater branches, ) hath endured and suffered more in their persons and fortunes, for obeying the Teachers of Romane Doctrine, then it hath done. ${ }^{5}$ 
His conversion was a gradual and considered process: "I used no inordinate hast, nor precipitation in binding my conscience to any locall Religion" (sig. B2v). Despite pressures from both sides, he resisted "any violent and sudden determination, till I had, to the measure of my poore wit and judgement, survayed and digested the whole body of Divinity controverted betweene ours and the Romane Church" (sig.B3r). This period of theological enquiry and inward debate is reflected in Satyre III, "Kinde pitty chokes my spleene": "Seeke true religion. O where? ... On a huge hill, / Cragged, and steep, Truth stands, and hee that will / Reach her, about must, and about must goe."6 Clearly it was no easy or casual matter for Donne to turn his back on the faith of his fathers and the heroic martyrdom for which his heritage might have seemed to predestine him:

I had a longer worke to doe then many other men; for I was first to blot out, certaine impressions of the Romane religion, and to wrastle both against the examples and against the reasons, by which some hold was taken; and some anticipations early layde upon my conscience, both by Persons who by nature had a power and superiority over my will, and others who by their learning and good life, seem'd to me justly to claime an interest for the guiding, and rectifying of mine understanding in these matters. ${ }^{7}$

Flynn adapts from Samuel Johnson the powerful phrase "laceration of mind" to describe the experience of Elizabethan converts like Donne from "Popery" to Protestantism. ${ }^{8}$

It was against this background that Carey read what he called the "elaborate blasphemies" of Donne's love poems: his persistent, indeed obsessive, use in flagrantly erotic contexts of such theologically charged terms as "Pilgrimage," "apostasie," "Martyrs," or "Reliques." The elegy "Change" is one among many potent examples, where Donne tells his mistress:

\footnotetext{
Although thy hand and faith, and good workes too, Have seal'd thy love which nothing should undoe, Yea though thou fall backe, that apostasie Confirme thy love; yet much, much I feare thee. ${ }^{10}$
}

"Faith" and "good works" were of course the key terms in the fierce debate between Protestants and Catholics about the means to salvation; here, though, they mean sexual constancy and sexual satisfaction. The mistress might "fall back" in the sense of lying down compliantly for her lover, an "apostasy" which paradoxically, wittily, shockingly, thereby comes to mean its opposite, a proof of fidelity. Carey regards Donne as "striving to neutralize ... unpleasantly significant words ... He handles holy things so as to cauterize himself." 11 We might recall Donne's description in Pseudo-Martyr, as quoted 
above, of his felt need "to blot out certain impressions of the Roman religion." Carey further suggests that in some of his more cynical love poems Donne's branding of women as sexually unfaithful is a displacement of his own guilt of spiritual infidelity; while conversely, in the poems which celebrate love as a transcendent experience, "love fills the crater left by apostasy."12

Although Donne's poems are notoriously difficult to date, it has been convincingly argued that the Elegies, which include numerous examples of religious imagery in erotic contexts, belong to the period 1593-96, when Donne was at the Inns of Court, with their culture of witty, virile, self-assertive young manhood. ${ }^{13}$ It is also plausible to place a significant number of the Songs and Sonnets before 1600 or even before $1598 .{ }^{14}$ Donne also of course allowed erotic imagery into his religious verse in troublingly unrestricted ways. In the Holy Sonnets, probably written between 1609 and $1611,{ }^{15}$ he once more mixes the sacred and profane. Holy Sonnet 13 contemplates the beauty of the crucified Christ, and analogizes alarmingly:

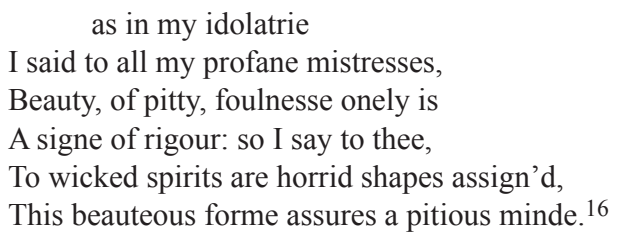

Within the syntactical knots, Donne transfers to the crucified Christ a seduction strategy of his youth, the argument that only ugly women say No. As Carey writes, "We cringe from the blasphemy." 17 Whereas in the erotic poems Donne's guilt of inconstancy was displaced onto women, it now returns home as a profound insecurity regarding his own worthiness to merit God's affection. ${ }^{18}$

It seems self-evident to us that Donne intended to shock. This seems especially certain in the light of Carey's invaluable restatement of the precise and fraught meanings, in their historical and biographical contexts, of the theological terms which Donne deployed. Yet, as any reader of Elizabethan poetry knows, Donne was far from alone in using religious imagery to praise a human mistress and to voice fleshly desires for her. In the 1590s boom in Petrarchan sonneteering, such rhetoric was endemic. The work which began the whole craze, Sir Philip Sidney's Astrophil and Stella, written in the early 1580 s but not published until 1591, eulogized Stella as "so true a deity," possessing heavenly beauty and virtue. ${ }^{19}$ Astrophil abased himself before her like a petitioner before the statue of a saint: "Grant, O dear, on knees I pray ... Shall a heavenly grace want pity?"20 Donne's clashing together of the 
erotic and the sacred seems highly unconventional to us; but would it have seemed so at the time? Was he shocking and original, and, if so, in what did his shock-value and originality lie?

A first stage in addressing these questions is to reconsider what might constitute blasphemy, and whether this would have been the same for an Elizabethan as for a modern reader. Such inquiry quickly discovers that blasphemy is a highly subjective and culturally variable phenomenon. The Oxford English Dictionary defines it as "Profane speaking of God or sacred things; impious irreverence." 21 But what is "profane"? We can turn onwards in the Oxford English Dictionary to find the definition "Not pertaining or devoted to what is sacred or biblical ... unconsecrated, secular, lay, common; civil, as distinguished from ecclesiastical" - a somewhat wide category. Nicholas Walter, in his book Blasphemy Ancient and Modern, offers a slightly lengthier exposition:

Blasphemy (from the Greek blasphemia, meaning offensive speech, especially in religious matters) may be defined very broadly as any offensive expression concerning God or the gods, other sacred persons or objects, religious doctrines or ideas, scriptures or liturgies, institutions or practices. ${ }^{22}$

There is some self-evident deferral of definition here too: what is "offensive"? Walter notes that the use of sexual imagery in religious contexts has generally been deemed blasphemous only if it was used to attack the established religion of the time or place; and that "Sometimes [blasphemy] is punished very severely indeed, to the extent of torture and death, and sometimes it isn't punished at all." 23

It may be that as modern readers in a predominantly secular age we want to regard Donne's poetry as blasphemous because we assume that his age was more religious than our own, and that therefore its boundaries between the sacred and secular were more rigidly policed. In fact the opposite may have been the case. A society permeated by religion, as late Elizabethan and Jacobean England undoubtedly was, may have been more accustomed to the extensive dissemination of religious references and resonances through all areas of culture. Moreover a long pre-Reformation poetic tradition, reaching back to the Song of Songs and medieval commentaries upon it, treated the Virgin Mary and courtly mistresses as virtually interchangeable objects of love-longing, and represented the relationship between Christ and the human soul in terms of wooing and yearning. Numerous examples include the lyric poems "Quia amore langueo" and "Maiden in the mor lay." 24

In applying the term blasphemy, then, we must be careful to do as Carey does and be as conscious as we can of the differences between past contexts 
and outlooks and our own. As a further stage in this we also need to examine whether, in an officially Protestant culture, specifically Catholic imagery, of the kind used so extensively by Donne, actually counted as religious imagery any more. In fact the religiose language found in parts of Astrophil and Stella quickly developed into a specifically Catholic vocabulary of love. Sir Arthur Gorges, in a sonnet of around 1584, lamented that a place from which his mistress was absent was "as a shryne where no Saynte is att all." 25 Samuel Daniel's Delia, first published in 1591, addressed "Teares, vowes, and prayers" to a mistress described as a saint; the speaker's love was "faith," and his sighs of affliction were clouds of incense. ${ }^{26}$ Michael Drayton in 1594 praised his Idea as "My Soule-shrin'd Saint," and beseeched her to

Receive the Incense which I offer here, By my strong Faith ascending to thy Fame,

My Zeale, my Hope, my Vowes, my Prayse, my Pray'r, My Soule's Oblations to thy sacred Name. ${ }^{27}$

Even the redoubtably Protestant Edmund Spenser falls in with this vein in the Amoretti of 1595, where his mistress is "my soverayne saynt, the Idoll of my thought," who "ought rather worshipt be" than loved. ${ }^{28}$

The same iconography can be found in Giles Fletcher's Licia (1593), Bartholomew Griffin's Fidessa (1596), and so on. ${ }^{29}$ There is a now-familiar dramatization of it in Romeo and Juliet (c.1594-5), where Romeo woos Juliet as a pilgrim at her shrine, and implores his "dear saint" to grant him a kiss "lest faith turn to despair." ${ }^{30}$ Next time they meet, Juliet urges Romeo to swear his fidelity "by thy gracious self, / Which is the god of my idolatry" (2.1.156). The word "idolatry," used by Donne in Holy Sonnet 13 to describe the profane loves of his youth, seems already in the 1590s to have come to mean not just the sinfully excessive adoration of saints by Catholics, but the passionate adoration of an earthly lover. Margaret Aston, in England's Iconoclasts, gives further examples, and comments that idolatry and cognate terms were now "poet's words for a dangerous extremity of love." ${ }^{31}$ It appears that incense, pilgrimages, shrines, the veneration of images, petitions to saints, and so on, all those religious practices specifically prohibited in postReformation England and denied to have any spiritual value, had become part of the standard furniture of erotic writing.

There are various ways of accounting for this. For instance, it may be that Protestant poets regarded the secularization and eroticization of Catholic iconography as an act of literary iconoclasm, contributing to the effort to render such iconography spiritually worthless. According to this reading, just as Donne handled the holy terms he was rejecting in order to neutralize them for 
himself personally, so Protestant love-poets were neutralizing those things sacred to the old faith on behalf of their whole culture. Aston's verdict is that "The ease with which poets found lovers "doting' in "mad idolatry" - she cites here A Midsummer Night's Dream 1.1.108-10 and Troilus and Cressida 2.2.56-60 - "shows how effectively the reformers, whose terminology was thus drafted into amorous service, had done their work." 32

One problem with such a reading resides in the fact that Petrarchan sonnets are evidently intended to celebrate and elevate a mistress, or secular love, but that purpose would be negated if the terms used had been entirely stripped of value. Alternatively, we may detect a survival in both popular and literary culture of images with a colour and vitality that outlived their religious significance. Sir Walter Raleigh's poem "Walsingham" illustrates this. It uses the form of a ballad about a pilgrimage to the Marian shrine, but quickly turns into a love poem:

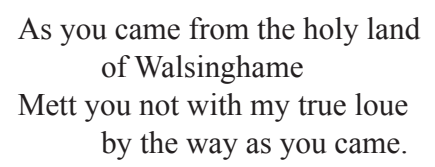

The beloved then turns out to be Queen Elizabeth:

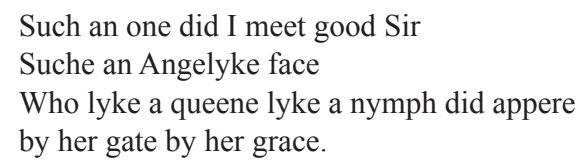

A pilgrimage ballad blends tranquilly into a love poem which in turn reveals itself as a piece of royal panegyric. A popular song known as "Walsingham" or "As I went to Walsingham" was current at the same time, though it is unclear whether it was the source of Raleigh's poem or vice versa. ${ }^{33}$

A third line of reasoning might be that Catholicism and sex are congruent in this period in being forbidden, taboo, risqué. The reverberation against one another of sex and religion in most contexts readily creates a frisson. To invoke prohibited religious practices arguably renders that frisson all the more intense. This might be the most helpful line of thought with which to return to Donne, since, with his distinctive family history, Catholicism was profoundly more forbidden to him than to contemporaries who were Protestant from birth. As we have seen, it seems that his journey away from the Catholic Church was a gradual, convoluted, and even tormented one, through the early to mid-1590s when many of his poems mingling Catholicism and eroticism were composed. ${ }^{34}$ The two were linked processes; the poems cannot with any 
certainty be divided into "before apostasy" and "after". But throughout this period we may reasonably surmise that the invocation of Catholic doctrines was a far more fraught experience for Donne than for others. As we have seen, we do not have to search far to find other examples of poets deploying religious and specifically Catholic iconography in secular contexts. Yet the experience of reading Donne's poetry is one of engagement with a mind far more original and less passive than would be implied by mere participation in a trend. Over and over again the force of his poetry seems to depend not on a mingling of the sacred and secular which has already become widely acceptable, but upon a sense that decorum is being not just breached but blasted; that things which should be kept apart are being explosively brought together.

As Carey says, the places where "We cringe from the blasphemy" are also places where "the voice lives," in a way that the voices of many 1590 s sonneteers do not. ${ }^{35}$ Carey further locates Donne's distinctiveness in his "turns and conflicts of thought": "What complicates the poems, and saves them, by its complication, from the usual mistress-worshipping paeans of Elizabethan poetry, is that they are simultaneously and indecisively sacred and secular, religious and anti-religious." 36 Certainly the level of theological abstraction and argument in Donne's poetry is of a far more intense and intellectual order than the fairly superficial use of external Catholic trappings - shrines, incense, pilgrimages - in the love poetry of most of his contemporaries.

In relation to this it is significant that, unlike most of the other $1590 \mathrm{~s}$ works mentioned above, Donne's love lyrics were not published in his lifetime and seem to have been intended only for manuscript circulation. The Songs and Sonnets in particular seem to have been confined by Donne to exposure to only a very small circle of known readers. ${ }^{37}$ They frequently depend upon jokes shared with his intimate audience about his indecorous use of terms recognized as having specific personal relevance to him. As Arthur Marotti has put it,

coterie work circulated in manuscript was often essentially self-advertizing, deliberately part of the social performance of an individual who could play the sometimes-bland generalities of poetic conventions against perceived particularities of his personality and personal situation (...) Donne (...) consistently exploited his readers' knowledge of his personal style and social circumstances to fashion distinctive utterances from literarily and culturally familiar material. ${ }^{38}$

Flynn makes a similar point, explaining that for his contemporary correspondents "Donne's lineage and social circle were connected, automatically and poignantly, to the notions of imprisonment and exile." 39 There is a cru- 
cial difference between the relatively placid use of decorative Catholic iconography by a securely Protestant poet, and the use of convoluted theological argument and of highly charged terms referring to central tenets of faith by a freshly apostate poet closely connected to Catholic martyrs. There is an irony here: if, as Carey puts it, Donne may have been seeking to "neutralize" Catholic terms for himself, he first had to reinvigorate their sacred value, in a wider culture in which they were already deconsecrated and neutralized.

Another difference between Donne and others is the overtness with which sexuality is treated by him. Many mistresses eulogized as saints by 1590 s sonneteers, such as Daniel's Delia, Fletcher's Licia, or Griffin's Fidessa, may not even have existed, let alone admitted the importunate poets to their bedchambers. Donne's mistresses, though, are accustomed to "falling back," as in "Change"; to undressing for bed in front of a naked man whose "flesh" is already "upright"; and to licensing roving hands to "goe / Behind, before, above, between, below" - and all this while being compared to an angel, an unbodied soul, and a mystic book. ${ }^{40}$ It is a critical commonplace to assert that Petrarchan sonneteers, even as they claim to venerate their mistress's virginity, clearly want to penetrate it; and that their neo-Platonic professions of being spiritually elevated by adoration from afar of their mistress's untouchable beauty merely mask or sublimate an unmistakably carnal desire. Such exposure of contradictions between manifest and latent content is by no means necessary for Donne's writing about sex. There can be little doubt that he has sex and that the women depicted in his poetry have sex. We may conclude that it is the juxtaposition of this unusual sexual frankness with an unusually technical, intellectual, and analytical invocation of theology that convinces us that Donne expected and wanted his readers to be startled and provoked.

Two other 1590s poets who made disconcerting juxtapositions of the religious and the erotic, and specifically the Catholic and the erotic, were Barnabe Barnes and Henry Constable. Both of them also had distinctive religious biographies which throw into relief the Elizabethan ideological landscape. By reading their poetry alongside Donne's, and in the light of these personal religious histories in a fashion similar to what has been done with Donne, it may be possible to explore a little further and assess a little more clearly the exact impact and import of Donne's poetry within its cultural context.

\section{II}

Barnabe Barnes's religious inheritance was the opposite of Donne's, being just about as respectably Church-of-England as you could get: he was the third son of Richard Barnes, Bishop of Durham. At Oxford he formed a lifelong 
friendship with William Percy, the brother of the Earl of Northumberland, and later gained Northumberland's own patronage. The Percys were a leading Catholic family, and Barnes's association with them brought him into contact with a Catholic circle; but there is no indication of any Catholic tendencies in his own writings, which include the very correctly Protestant Divine Centurie of Spirituall Sonnets (1595), and a virulently anti-Catholic revenge tragedy, The Devil's Charter (1606).

According to his enemy Thomas Nashe, Barnes was chiefly known for extravagant and absurd behaviour, for example:

because hee would bee noted, getting him a strange payre of Babilonian britches, with a codpisse as big as a Bolognian sawcedge, and so went vp and downe Towne, and shewd himself in the Presence at Court, where he was generally laught out by the Noble-men and Ladies. 41

This character-portrait is in various respects corroborated by Barnes's 1593 publication, Parthenophil and Parthenophe, a sequence of sonnets interspersed with poems in other forms. Parthenophil (meaning "lover of a virgin") repeatedly and somewhat tiresomely draws attention to his erection as he pursues Parthenophe (meaning "virgin"). ${ }^{42}$ Unlike those many other Petrarchan sonneteers who purported to venerate their mistress's virginity even as they desired to overcome it, Barnes/Parthenophil consistently and perhaps less hypocritically complains of her virginity as an infuriating obstacle. ${ }^{43} \mathrm{He}$ longs to feel "her enfolded thighes in mine entangled" and "my long pleasure in her body grafted." 44 His imprecation to Venus is uncomplicated: "That I my sweet Parthenophe may get."45

One poem which created some stir was sonnet 63 . The speaker contemplates Jove's erotically motivated metamorphoses, then wishes to be transformed into his mistress's gloves, so that he could kiss her "white louely fingers." Predictably, this develops into an imaginary journey to other parts of the body: his next wish is to become

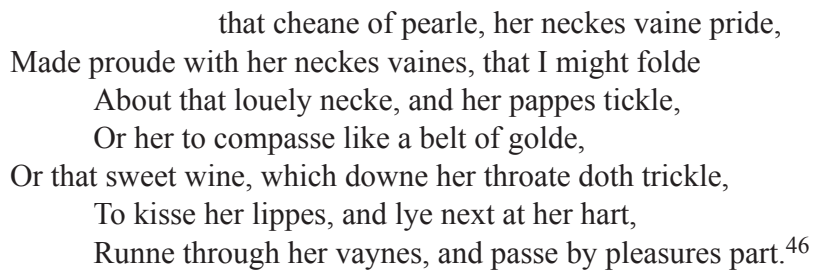

In case the reader hesitates to take Barnes's meaning, it may be spelled out even more crudely: he wishes to be the wine drunk by his mistress so that 
he may become her urine and so pass by her vagina. The poem-sequence ends on an extraordinary crescendo as, in a frenzied nocturnal occult ritual, a goat bears the naked Parthenophe to the exultant Parthenophil. Parthenophil achieves orgasmic closure: "as she once with rage my bodie kindled, / So in hers am I buried this night." 47 As Barnes's modern editor dryly notes, this constitutes "an unconventional relief for the woes of the Petrarchan lover." 48

Critics who enjoy Barnes's verse have praised its exuberance and originality; it is the voice of a young man who "tried everything once." 49 Moreover, Parthenophil and Parthenophe shows remarkable technical proficiency and range, including not just sonnets but also madrigals, sestines, canzons, elegies, an eidillion, and odes in various sophisticated metres; as one twentieth-century biographer remarked, this shamelessly salacious, intermittently absurd and unsavoury, technically accomplished poem-sequence "is a somewhat remarkable achievement for a boy hardly twenty-two." 50

In the course of Parthenophil Barnes frequently participates in the 1590 s convention of addressing his mistress as a saint. Having all the beatific graces, she should concede "That sainctes deuine are knowne sainctes by their mercy." His burning passion "is as an incense to my soule." ${ }^{51}$ However, the explicit carnality of his desire makes it apparent that the "mercy," "pity," or "relief" he seeks clearly stand for sexual generosity. This becomes especially evident in Ode 3:

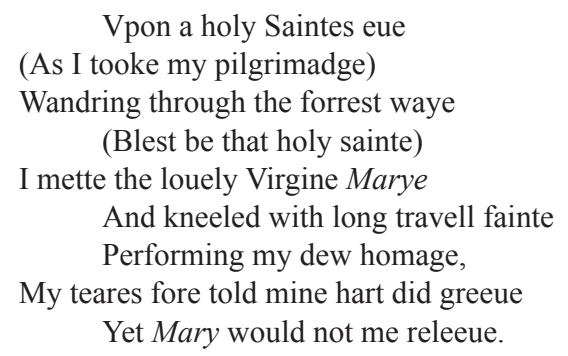

Read against the incessant expressions throughout the poem-sequence of sexual arousal and of frustration at Parthenophe's rigid and unrelenting dedication to virginity, this is clearly no straight-faced prayer to the Virgin Mary for assistance in a chaste courtship, but a plea to a virgin named Mary (presumably Parthenophe's real name) to drop her sexual defences. ${ }^{52}$

The second stanza develops the theme: 


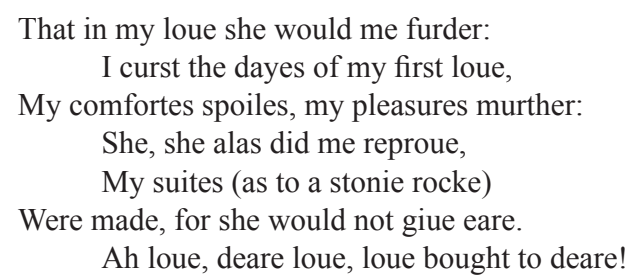

Adopting a Spenserian pastoral pose, Parthenophil at once merges and separates his mistress Mary and the statue of the Virgin Mary to whom he pleads for intercession. He offers the intercessory figure his "firstling foemales," that is, his virginal conquests - assuming others both before and after Parthenophil. But she remains unresponsive "as ... a stonie rocke," a joke about the fact that this is after all only a statue of the Virgin, and, simultaneously, a metaphorical merging of that statue with his stonily unyielding mistress.

The third and final stanza continues this mingled separation and blurring of intercessor and mistress:

Mary, my sainte chast, and milde

Pittie, ah pittie my suite;

Thou art a virgine, pittie mee:

Shine eyes, though pittie wanting

That she by them my greefe may see

And looke on mine hart panting:

But her deafe eares, and tonge mute

Shewes her hard hart vnreconcil'de,

Hard hart, from all remorse exil'de. ${ }^{53}$

The next poem gives up on the Virgin Mary and turns instead to Bacchus, asking him for a potent erection in order "The rightes of loue to celebrate" with, or on, Parthenophe. ${ }^{54}$

To a modern reader this flagrantly sexual invocation of the Virgin Mary seems undoubtedly to require the term "blasphemy." But would it have seemed so to the loyally Protestant son of a Church of England bishop? Of course even for a Protestant it would have been indecent to represent the mother of Christ in such terms; but Barnes is here specifically invoking not the Virgin Mary in person so much as the Catholic practices of pilgrimages to shrines and prayers for intercession, precisely those practices which Protestantism vilified as idolatrous and sinful. To relegate such practices to displays of wit in erotic verse might have seemed like an entirely proper Christian thing to do, an act of literary iconoclasm. The pastoral setting here and the offering up of sacrificial lambs conflate the Virgin Mary with such pagan goddesses as 
Diana or even Venus, parodying exactly what Protestant polemicists accused Catholics of doing in their excessive adulation of images of the Virgin.

Barnabe Barnes's father, Bishop Richard Barnes of Durham, had published a series of Injunctions for his diocese between 1575 and 1587 which included directions not only to ensure that there were no images in churches, but to obliterate all traces of where they had stood. He commanded that:

All balks or hearses, whereupon lights or serges were in time of popery used to be set, and all the remnants of roodlofts and remnants of altars, and all corbel-stones whereupon images have been placed, be utterly removed out of the churches and chapels before Christmas next, and the places where they stood pargetted over with lime ... as if there had been no such thing there. ${ }^{55}$

A generation on, his son retrieves an imagined statue of the Virgin from this obliteration, but only in order to desecrate it; the two stances are clearly not incompatible.

A further alternative interpretation of Barnes's poem might be that pilgrimages, images, and shrines had passed so far back into history and folklore by this time that they were no longer the threatening, fearful phenomena they clearly were to his father, and instead were available as relatively neutral, merely decorative motifs for a Protestant poet to employ in his secular verse. Overall, we may sense that Barnes is having it all ways: creating that frisson effect of rubbing up religion — and forbidden religion at that — against sex, while not doing anything that was theologically improper in a Protestant state.

Of course the really shocking thing to do would have been to write seriously about petitioning the Virgin Mary in a religious work. A 1599 edition of poems by the Jesuit martyr Robert Southwell was extensively edited by the printer to excise references to the Virgin. ${ }^{56}$ If we turn to Barnes's own Divine Centurie of Spirituall Sonnets, published two years after Parthenophil in 1595, we find that, good Protestant that he is, he is careful to keep the Virgin Mary and the cults of saints well clear of this devotional work. All the sonnets are addressed to Christ or to God the Father. There is only a single mention of the Virgin in the whole volume, in a closing hymn to the Trinity, where she figures merely as a vessel for the Holy Spirit, "By whose power in the Virgines wombe did spring / Our comforter and King." ${ }^{57}$ When saints are mentioned, it is in the plural Protestant sense of the Elect. ${ }^{58}$ Erotic imagery is also notable for its paucity: the nearest Barnes comes to it is in eulogies of the beauty of the merciful Christ, and in pleas for spiritual ravishment which prefigure Donne's Holy Sonnet 14. Barnes tells Christ that he longs to be "Rauish'de with loue of thee," and implores, "Kindle my spirit with that 
sacred heate, / Which me may rauish with an heauenly loue." Again he beseeches, "Rauish my senses with celestial fits." 59 If Donne in Holy Sonnet 14 is a reformed seducer yearning to change places and be battered and ravished by a divine lover, then Barnes/Parthenophil similarly is a former rapist turned willing ravishee.

Accordingly, another repeated strain in the Divine Centurie is penitence for Barnes's depraved way of life, and admonitions to other poets to follow him in turning their skills away from the blazoning of earthly mistresses to the hymning of God. ${ }^{60}$ Meanwhile, Barnes had made literary enemies, including Thomas Nashe and Sir John Harington, and they were not slow to mock his abrupt change of theme. ${ }^{61}$ Parthenophil and Parthenophe had already attracted mirth, especially sonnet 63 , the one quoted above where Parthenophil desires to be the wine drunk by his mistress and passing through her body. Nashe scoffed,

if you would haue anie rymes to the tune of stink-a-pisse, hee is for you. In one place of his Parthenophil and Parthenophe, wishing no other thing of Heauen, but that hee might bee transformed to the Wine his Mistres drinks, and so passe thorough her ... Therein hee was verie ill advisde, for so the next time his Mistres made water, he was in danger to be cast out of her fauour. ${ }^{62}$

Campion and Marston also joked about this particular poem. ${ }^{63}$

Even Barnes's friends focussed on sonnet 63 when applauding him: Thomas Bastard wrote in 1598, "Barneus' verse (vnlesse I doe him wrong,) / Is like a cupp of sacke, heady and strong." 64 Clearly this was the poem for which Barnes was famous, or infamous. What is striking about these various reactions to it is that none of his contemporaries, whether friend or foe, seems to have commented on the Virgin Mary ode, Ode 3, which strikes the modern reader as being at least as controversial. As with the Ode itself, it is difficult to judge how to interpret this apparent silence. It is just possible that Barnes's contemporaries regarded the Ode as too crass and tasteless to be discussed, although it is hard to imagine Nashe, say, exercising restraint when such useful material for his satire of Barnes lay readily to hand. Perhaps again we should read the lack of reaction as evidence that to invoke the decorative aspects of Mariolatry in an erotic poem was not at all shocking to Protestant Elizabethans, and may, indeed, have been seen as entirely appropriate.

\section{III}

Henry Constable has a religious biography which, while quite different from Barnes's, is also in its way the opposite of Donne's. Born in 1562, as a young 
man he worked for Walsingham in various European countries, and was also an emissary to the Scottish court for the Earl of Essex. By the late 1580s he was enjoying the sort of highly promising career in the service of the Elizabethan government and court that would have made the young Donne green with envy. Then, in 1589-90, he converted to Catholicism; as one commentator put it, he resolved "to lose all his heritage in order to save his soul." Grief at his conversion was said to have caused his father's death. Although he continued to profess patriotism, and to engage energetically in various international negotiations in which he hoped to undo the English definition of Catholicism as treason, he was forced to live in exile from 1591 to 1603. After returning to England he endured several periods of imprisonment, until he left for France again in 1610, and died at Liège in 1613.65

Constable was considered a major poet in his day, a reputation largely based upon his sonnet-sequence Diana. This was published after his exile, in 1592, and again, in a differently ordered version, in 1594; a number of manuscript copies of his poems were also in circulation. ${ }^{66}$ Diana comprises not only love poems but also, befitting a young man with aspirations as a courtier, panegyrics of patrons, potential patrons, and even the monarchs of England and Scotland themselves. It is thought that these secular poems had probably all been composed by the end of 1590 , that is before, but perhaps also overlapping with, the time of Constable's conversion. ${ }^{67}$

The poems to a mistress or mistresses do not stint in their use of devotional language. Her beauty works miracles; her glove is to be kissed "as a thinge deuine ... thy reliques shrine"; she is routinely and repeatedly addressed as a "diuinitye." 68 Constable argues that it is no idolatry to adore her, since she truly is divine: "Thy image should be sunge for thow that goddesse art / Which onelye we withoute idolatrye adore." ${ }^{69}$ A sonnet entitled "Of his Mistrisse vpon occasion of a friend of his which disswaded him from louing" deploys a seductive rhetoric not far removed from Barnes's Virgin Mary ode, though Constable is less pressing and blatant in his sexual requests, asking only for "favoure":

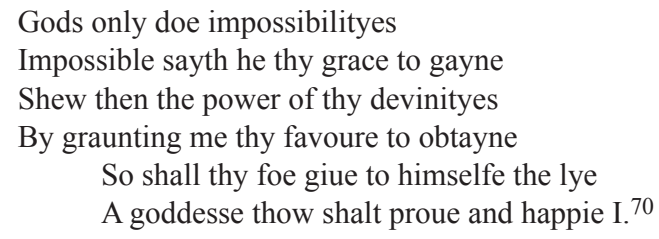

It may be that the entirely non-Christian word "goddess" is crucial in these instances, signalling to Elizabethan readers that Constable only means to 
place his mistress in a secular, literary pantheon of pagan, classical divinities, and of other similarly lauded Petrarchan mistresses.

Even so, some of the imagery in Part III of Diana seems highly charged when delivered by the pen of a man contemplating or perhaps in the process of conversion to Catholicism. The first set of sonnets in this section comprises "seuerall complaynts of misfortune in loue onlye," in which Constable writes vividly of torture and confession:

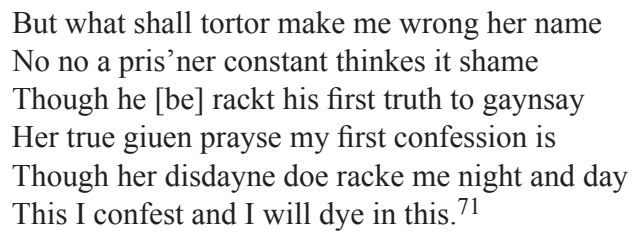

There follow a set of sonnets "To Sir Philip Sydnyes soule," eulogizing a hero of militant Protestantism; indeed, throughout Diana, notable Protestant figures are celebrated, including Sidney's sister, the Countess of Pembroke; his widow, now the Countess of Essex; and the Princess of Orange, who is offered condolences for the murder of her father and husband during the St Bartholomew's Day Massacre. ${ }^{72}$ However, in the last seven sonnets, "of the end and death of his loue," a strain of imagery returns which resonates unsettlingly with the state punishment of Catholicism. The pain of rejected love is said to be like a death sentence, and the poet wishes

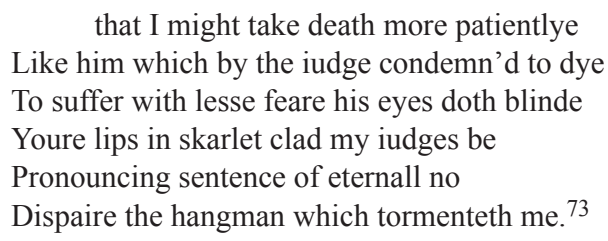

Whatever Constable's religious allegiance at this point, the use of such imagery in the relatively trivial context of a love poem, at the end of a decade which had seen the tortures and gruesome executions of Catholics like the Babington conspirators and Edmund Campion, seems somewhat grotesque.

It is in the political and patronage poems of Diana that developing tensions between Constable's civil and spiritual fealties become most evident. One of his chief patrons and protectors was Lady Mary Talbot, a Catholic, who in November 1590 became Countess of Shrewsbury. Constable addresses the following remarkable sonnet to her: 


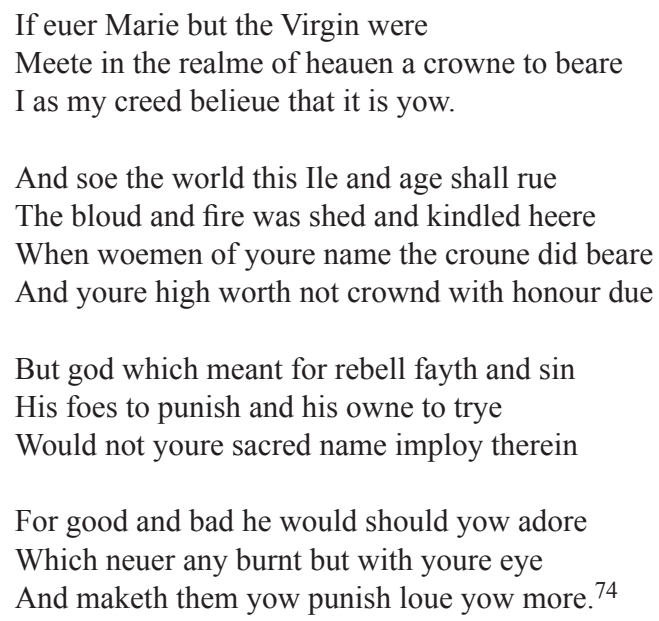

In a brilliant reading of this sonnet, Alison Shell has shown how its opening declaration of plain speaking is immediately confuted by the ambiguities which follow. Shell writes:

The line "I as my creed believe that it is yow" authenticates his admiration for the Countess; but, gratuitously raising the question of Constable's creed, it redirects the reader to the unresolved theological crux in the previous lines. The doctrine of the Assumption and Coronation of the Virgin was traditional rather than biblical. ${ }^{75}$

Most Protestants would not have agreed that the Virgin Mary was already crowned in heaven, though they would have agreed that she was "meete" to bear a heavenly crown. It is impossible to detect from the first quatrain of the sonnet where Constable stands on this; his own position, even if he were certain of it at this point, is scrupulously concealed at exactly the point where he provocatively draws attention to the question of which "creed" he subscribes to. Similarly, a Catholic Mary who burned religious opponents in her reign as Queen Mary I is deplored, even as two other Catholic Marys, the Virgin and Mary Talbot, are exalted. Was Mary Tudor guilty of "rebell fayth and sin"? If so, is Mary Talbot? - presumably not, since her name is "sacred" (line 11). Who exactly are God's "owne"? - Catholics, or Protestants, or a more select group still of right-doers and true believers? Finally, the conclusion of the poem, again transposing the imagery of martyrdom to the effects of a lady's beauty, like the sonnets on enduring the death of love, verges upon the tasteless when we consider its historical context.

Part II of Diana also contains a set of seven sonnets addressed to Elizabeth I and to James VI of Scotland. The first of these, "To the Q: after his returne 
oute of Italye," looks at first like a straightforward exercise in royal panegyric, describing the praises of Elizabeth's wisdom and glory which Constable has heard on his travels in Europe. Then comes the unexpected line: "Thine eye hath made a thousand eyes to weepe." 76 The poet argues that, even if some miracle were to dry up the oceans which surround England and render her secure, the tears provoked by Elizabeth would form thousands of seas to protect her. The reader is left to question whether these tears are merely notional and complimentary Petrarchan ones, as Constable adopts the conventional courtly pose of one among many unrequited lovers of the radiant Virgin Queen; or whether they are tears of a more profound grief instigated by some more sinister property in her. The following sonnet, "To the Queene touching the cruell effects of her perfections," takes up and develops this same ambiguity:

\footnotetext{
Most sacred prince why should I thee thus prayse Which both of sin and sorrow cause hast beene Proude hast thow made thy land of such a Queene Thy neighboures enviouse of thy happie dayes.
}

Whoe neuer saw the sunshine of thy rayes An euerlasting night his life doth ween And he whose eyes thy eyes but once haue seene A thowsand signes of burning thoughts bewrayes

Thus sin thow causd envye I meane and pride Thus fire and darknesse doe proceed from thee The very paynes which men in hell abide

Oh no not hell but purgatorie this Whose sowles some say by Angells punish'd be For thow art shee from whome this torment is. ${ }^{77}$

Elizabeth is the source simultaneously of sun-bright beams, and of fire and darkness. The sonnet is conflicted and anguished: it seems to want to go through the conventional motions of panegyric, praising Elizabeth's perfections even as it laments the distress they cause in mere mortals, but at the same time the terms used for that distress are so forceful and embittered that they imply her personal culpability of unspecified crimes and evils. She is an agent of "torment."

Meanwhile, the word "purgatorie" has inescapable Catholic connotations. This doctrine was forcefully repudiated in the Church of England's 39 Articles of Faith, which stated under the heading "Of Purgatorie": 
The Romishe doctrine concernyng purgatorie, pardons, worshipping and adoration aswell of images, as of reliques, and also invocation of Saintes, is a fonde thing, vainly invented, and grounded upon no warrauntie of Scripture, but rather repugnaunt to the worde of God. ${ }^{78}$

Again it is hard to detect whether Constable sincerely believes in purgatory as a part of his "creed," or whether he is merely drawing on it as an expressive poetic image. Donne does the latter in the elegy "Recusancy," where he addresses his heartless mistress as "my Purgatory, faithlesse thee"; 79 and so does Michael Drayton in a sonnet from the 1599 Idea, where "Purgatorie" is the condition of one "whose Spirit Love in his fire refines." 80 Purgatory may be one of those terms and ideas which, despite being outlawed by the official Church, had passed into the popular imagination. It seems that even before the Reformation it was less significant in the rituals of the Church than it was in the religious traditions and practices of the laity and in popular beliefs concerning the fate of the dead. Consequently, belief in purgatory seems to have persisted with some resilience. ${ }^{81}$ Hamlet's dead father seems to think that he is there:

\footnotetext{
Doomed for a certain term to walk the night, And for the day confined to fast in fires Till the foul crimes done in my days of nature Are burnt and purged away. ${ }^{82}$
}

Despite much scholarly inquiry into the subject, it remains entirely uncertain whether we should read this as evidence of Shakespeare's Catholicism, or of the prevalence of concepts like purgatory in popular mythology despite the doctrinal innovations of the Reformation. ${ }^{83}$ Stephen Greenblatt has written eloquently of how Shakespeare sets up a "network of allusions" to purgatory in Hamlet which are numerous and prominent yet at the same time "cautiously equivocal," such that the "intricate arguments" of scholars who have probed and debated Shakespeare's beliefs are "doomed to inconclusiveness." 84 Constable similarly puts before us the word and the idea of purgatory while leaving us entirely uncertain as to whether he is merely employing it as part of the standard vocabulary of the passion-stricken Petrarchan lover, or deploying it as a loaded term invoking Elizabeth's persecution of Catholics. Are the "burning thoughts" which Elizabeth inspires in onlookers thoughts of ardent devotion to her, or thoughts of her burnings of Catholic martyrs?

Constable continues to wrestle with his shifting allegiances in his Spirituall Sonnettes, which circulated only in manuscript. They are not precisely datable, but clearly fall after his conversion. A series of sonnets "To our blessed Lady" argues out the Virgin Mary's pre-eminence over those troub- 
ling earthly queens. Constable admonishes, "Cease then, O Queenes who earthly crownes do weare / to glory in the pompe of worldly thinges." If the "daughters, wyves, \& mothers" of kings are to be revered, how much more the heavenly Queen "Who had your God, for father, spowse, \& sonne." 85 In a further poem to the Virgin, Constable implores,

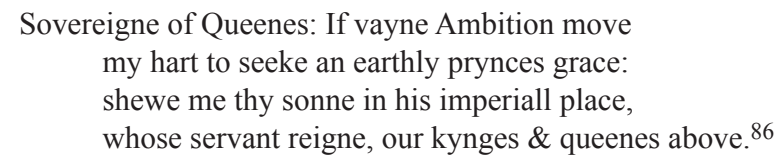

And again, he asks "Why should I any love O queene but thee?", since the promise of the glorious sight of the Virgin in heaven fulfils the cravings both of pleasure and ambition. ${ }^{87}$ Even as Constable turns away from earthly monarchs we feel the emotional and psychological cost to him in doing so; he has to argue the case over and over again, and he still mentally configures the reasons for faith in the political and courtly terms of service to monarchs, aspiration, and high reward.

Constable seeks in the rewards of faith compensation not only for his sacrifice of his political ambitions, but also for his abjuration of sensual pleasures. The "lovely face" of the Virgin will dispel "alluryng passions" and bring his heart to "chaste desyres." 88 Again, though, these desires, while "chaste," continue to be represented in terms that reproduce the earthly "alluring passions" that are being left behind. Constable writes "To our blessed Lady":

$$
\begin{aligned}
& \text { thy sight, gyves vs possession of all ioye, } \\
& \text { And with such full delyghtes ech sense shall fyll, } \\
& \text { as harte shall wyshe but for to see thee styll, } \\
& \text { and ever seyng, ever shall inioye. }{ }^{89}
\end{aligned}
$$

Love of the beauty of the Virgin will raise the poet, neo-Platonically, to love of the beauty of God, which will offer even more rapturous satisfactions:

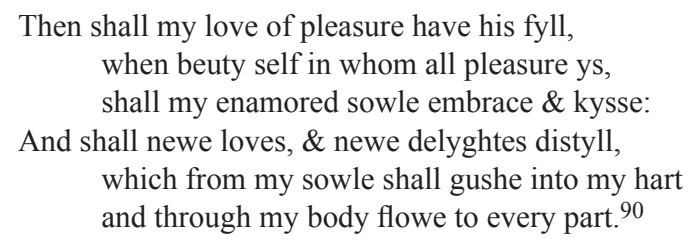

In the pursuit of this transcendence and union with the divine, Constable, like Donne and Barnes, often imagines himself in the place of a female lover. In a sonnet "To Saint Margarett," he praises her virginity as the source of her 
power to defeat the devil, and prays "let my soule mayd chaste, passe for a Mayde." "A1 Another, "To Saint Mary Magdalen," declares that "lyke a woman spowse my sowle shalbee":

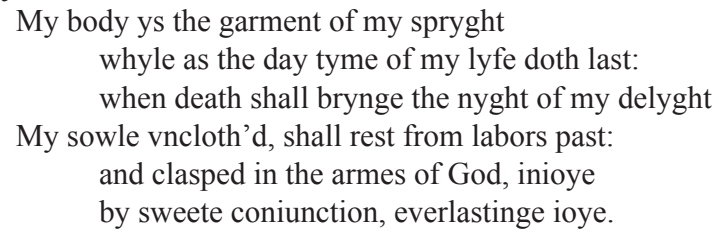

This is the climax to the whole sequence of Spirituall Sonnettes, subscribed "\& Amen. \& Amen. Amen." 92 Much more than Barnes, Constable allows his religious verse to be flooded with the kind of sensual expression of spiritual ecstasy associated with the Counter-Reformation aesthetic of figures like Saint Teresa of Avila (1515-82), and which would be developed in English Catholic poetry by Richard Crashaw (1613-49).

A similar literary response to conversion may be observed in the writings of William Alabaster (1568-1640), a Cambridge minister, academic, and poet who became a Catholic in around 1597. Arthur Marotti writes that Alabaster's post-conversion language "echoes some of the terms of baroque Catholic devotion," 93 as seen in his narrative of his conversion: "so soone as I was a Catholique, I fealt such illustrations and illuminations of mynde, such joye, such content, such aboundance of teares such tender devotions, such flames of ardent love towardes Christ ...."94 Like Constable, Alabaster turned to writing religious sonnets, in which more of this baroque and sensual language may be seen. Alabaster writes of his "Hot love of Christ" which "melt[s] in tears mine eyes," 95 and of the seductive wooing of mankind by God:

God was in love with man, and sued then

To get return of love by all those ways

Which lovers use to compass in their praise. ${ }^{96}$

Contemplating Christ upon the cross, he cries, "Feed greedy eyes ... let my lips from kissing not remove," and longs to be a climbing plant so that he can wind himself around Christ's beautiful body,

And kiss his feet with my ambitious boughs, And climb along his sacred breast,

And make a garland for his wounded brows. ${ }^{97}$

In another sonnet contemplating the crucifix, Alabaster pictures how "from his side the blood doth spin, whereon / My heart, my mouth, mine 
eyes still sucking be." 98 Marotti finds in the writings of Alabaster and his contemporary co-religionists a "distinctly Catholic perception of the interpenetration of the spiritual and physical," and to encapsulate this he usefully borrows from Michael O'Connell the phrase "incarnational aesthetic." 99 This phrase is extremely apt for Alabaster's poetry, not only because of his recurrent preoccupation with the Incarnation and the Passion - in short, God made flesh-but also because of his tendency to express spiritual experience in terms of bodily sensation. Evidently for both Alabaster and Constable conversion gave them access to, and freedom to develop, a sensual language of intense religious experience.

\section{IV}

The cases of Barnes and Constable, like that of Donne, demonstrate that, in the midst of a general poetic fashion for mingling the sacred and the erotic, individual histories and contexts produce idiosyncratic variations on the theme. Barnes's Ode 3 shocks the modern reader, and occurs in the course of a poem-sequence whose sexual frankness, like Donne's, seems designed to provoke; but in the hands of a respectably Protestant poet this analogizing between the seduction of a mistress and the idolatrous practice of petitioning a Marian statue may have functioned at a teasing level of schoolboyish, pranksterish humour rather than outrageous blasphemy. Constable, on the other hand, as a Catholic, is able to perpetuate the pre-Reformation tradition of using erotic language to express spiritual experience, adding into this the developing Counter-Reformation aesthetic of sensuality in devotion; the availability to him of the figures of the Virgin Mary and female saints facilitates this. Neither Barnes nor Constable, though, goes quite so far as the violence of Donne's "Batter my heart," or his Holy Sonnet 13's redirection to Christ of a seduction technique for "profane mistresses" which was self-consciously disgraceful in the first place.

In the writings of all three poets, sexuality is invoked for its dangerous and thrilling potency; but the force of its combination with Catholic language differs widely between each case. For Barnes Catholicism at once connotes the culturally forbidden, and something which is nothing to do with him. For Constable Catholicism comes to be the very means of defining himself. But for Donne Catholicism is simultaneously an innate part of himself and something forcefully repudiated, forbidden not just by culture and law, but by a profound and anguished personal choice. Hence the production of much more than just a frisson by his combinations of Catholicism and eroticism. For both Donne and Constable conversion was a process, not a momentary 
revelation. As a result, Donne's use of Catholic terms is marked by various kinds of indeterminacy. Where does he speak from: inside or outside Catholicism? Does he know? What exactly is he flouting? This indeterminacy is itself a strong and perhaps self-conscious ingredient in the unsettling effect of his use of Catholic terms.

As we move on into the early decades of the seventeenth century, Donne's poems become widely known through both extensive manuscript circulation and the print publication of his poems in 1633, and we find his idiosyncrasy itself becoming a dominant cultural influence. Thomas Randolph (1605-35), for example, one of the "Tribe of Ben," the friends and disciples of Ben Jonson, also wrote in a recognizably Donnean mode. An elegy opening "Love, give me leave to serve thee, and be wise" echoes Donne's "Exstasie" in its use of intensely tactile imagery to describe the communion of two souls: "When essence meets with essence, and soules joyne / In mutuall knots, thats the true Nuptiall twine." Specifically Catholic imagery is used to evoke not only a neo-Platonic devotion, but also the thrilling pleasure of touch:

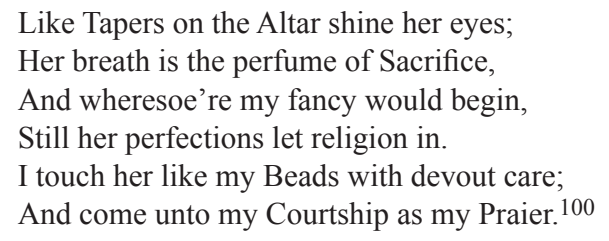

Randolph had no connection with the Catholic Church, and is very unlikely to have owned any rosary beads other than in the realm of poetic imagination. We see Donne's singularity itself passing into general poetic convention. Similarly Thomas Carew, a poet influenced by both Donne and Randolph, wrote in his erotic poem "A Rapture" in the 1620s:

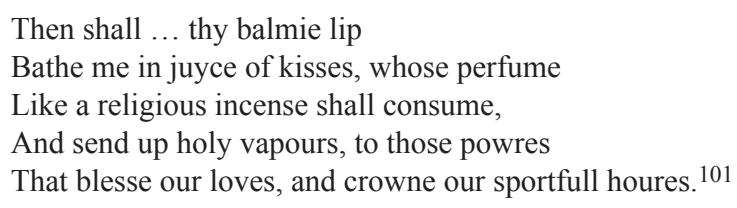

Carew's poem had some notoriety, and when his Poems appeared in print in 1640 they were denounced in parliament by Sir Edward Dering as being "in disgrace of Religion, \&c. to the increase of all Vice, and withdrawing of the people from reading studdying, and hearing the word of God." 102 Dering's objection, though, seems to have been to the generally pornographic qualities 
of some of Carew's verse. It was left to Catholics to object specifically to the appropriation of their forms of worship by erotic poets. Edward Thimelby, a Catholic, lamented in the 1650s that

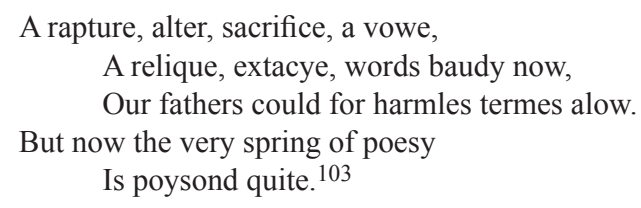

As we have seen, Donne was by no means the sole agent of this innovation in poetic language; but he was certainly one of the most enduring in influence. In the 1590s he brought an idiosyncratic extremity to a mostly relatively bland poetic fashion, for reasons which can be convincingly explained in terms of his unusual biography; but a few decades later, his unconventionality had itself become the convention. Edward Thimelby deplores the fact that what to him as a Catholic is blasphemy-indeed what Donne perhaps deployed precisely because it felt blasphemous and dangerous to him-has now, in the wider culture, become merely commonplace. For us as twenty-first century readers, it takes on a new and different kind of strangeness again.

\section{University College London}

\section{Notes}

I am grateful for responses to this essay from Alison Shell and from the Oxford University Renaissance Research Seminar, to which I was kindly invited by Katherine DuncanJones. An earlier version of the essay was written in honour of John Carey on his retirement; the present version is also dedicated to him.

1. Arthur Marotti, "John Donne's conflicted anti-catholicism," Journal of English and Germanic Philology 101.1 (Jan 2002), p.358.

2. John Carey, John Donne: Life, Mind and Art (London: Faber, 1981), pp. 15-24, 18.

3. Dennis Flynn, John Donne and the Ancient Catholic Nobility (Bloomington and Indianapolis: Indiana University Press, 1995), p. 176.

4. John Donne to Elizabeth Rainsford, undated, in Toby Matthew, A Collection of Letters Made by Sir Tobie Matthew, Knt. (London, 1660), p. 324.

5. John Donne, Pseudo-Martyr (London, 1610), "An Advertisement to the Reader."

6. John Donne, The Satires, Epigrams and Verse Letters, ed. W. Milgate (Oxford: Clarendon, 1967), pp. 10-14, lines 43, 79-81.

7. Donne, Pseudo-Martyr, sigs B2v-3r.

8. Flynn, p. 12. 
9. In "Goe, and catche a falling starre," "Change," "The Bracelet," and "The Funerall." John Donne, Elegies and the Songs and Sonnets, ed. Helen Gardner (Oxford: Clarendon, 1965), pp. 29, 19, 3, 91. See Carey, pp. 38-46.

10. Donne, Elegies and the Songs and Sonnets, p. 19, lines 1-4.

11. Carey, pp. 39, 41.

12. Carey, pp. 38,45 .

13. Donne, Elegies and the Songs and Sonnets, pp. v, xxxiii.

14. Donne, Elegies and the Songs and Sonnets, pp. v, li-lix; John Donne, The Songs and Sonnets of John Donne, ed. Theodore Redpath, 2nd ed. (London: Methuen, 1983; 1st ed. 1956), p. 4.

15. John Donne, The Divine Poems, ed. Helen Gardner, 2nd ed. (Oxford: Clarendon, 1978; 1st ed. 1952), p. xlix-1.

16. Donne, Divine Poems, p. 10.

17. Carey, pp. $47,54$.

18. Carey, pp. 57-9.

19. Sir Philip Sidney, Astrophil and Stella, in Katherine Duncan-Jones, ed., The Oxford Authors: Sir Philip Sidney (Oxford, New York: Oxford University Press, 1989), p. 154, sonnet 4, line 13; p. 195, 7th song, stanza 3; and passim.

20. Sidney, p. 197, 8th song, lines 49, 64.

21. The Oxford English Dictionary on CD-ROM.

22. Nicholas Walter, Blasphemy Ancient and Modern (London: Rationalist Press Association, 1990), p. 8.

23. Walter, pp. 16,8 .

24. Helen Hackett, Virgin Mother, Maiden Queen: Elizabeth I and the Cult of the Virgin Mary (Houndmills: Macmillan, 1995), pp. 15-18.

25. The Poems of Sir Arthur Gorges, ed. Helen Estabrook Sandison (Oxford: Oxford University Press, 1953), p. 67, no. 65, line 4. For discussion of date, see pp. xxvii-xxxii, and Steven W. May, The Elizabethan Courtier Poets: The Poems and Their Contexts (Columbia, Missouri: University of Missouri Press, 1991), pp. 103, 323.

26. Samuel Daniel, To Delia, 1594 text, in Maurice Evans, ed., Elizabethan Sonnets (London: Dent/Everyman, 1977), pp. 62-86, esp. sonnets 5, 6, 8, 11, 12, 36, 38, 42, 44, 55.

27. Michael Drayton, Idea, in Evans, ed., pp. 109-10, sonnets 53 \& 54; \& see p. 111, sonnet 57 (from the 1605 text).

28. Edmund Spenser, Amoretti (1595), in Evans, ed., p. 140, sonnet 61. See also p. 123, sonnet 22 .

29. Evans, ed., p. 167, sonnet 17; p. 169, sonnet 41; p. 177, sonnet 39; Bartholomew Griffin, Fidessa, more chaste than kinde (1596), sig. D2v, sonnet 36.

30. William Shakespeare, Romeo and Juliet, in The Norton Shakespeare, ed. Stephen Greenblatt et al. (London, New York: Norton, 1997), 1.5.90-107.

31. Margaret Aston, England's Iconoclasts Volume I: Laws Against Images (Oxford: Clarendon, 1988), p. 466-7. 
32. Aston, p. 467.

33. Hackett, Virgin Mother, pp. 155-60.

34. Carey, pp. 26-30.

35. Carey, pp. 47, 54

36. Carey, p. 45.

37. Donne, Elegies and the Songs and Sonnets, pp. xlix-1; Arthur Marotti, John Donne, Coterie Poet (Madison: University of Wisconsin Press, 1986), p. 16.

38. Marotti, John Donne, Coterie Poet, p. 14.

39. Flynn, p. 175.

40. Donne, "To his Mistris Going to Bed," Elegies and the Songs and Sonnets, pp. 14-16.

41. Thomas Nashe, Haue with you to Saffron-walden (London, 1596), facs. (Menston: Scolar, 1971), sig. R2r.

42. Barnabe Barnes, Parthenophil and Parthenophe (London, 1593), ed. Victor A. Doyno (Carbondale \& Edwardsville: Southern Illinois University Press, 1971), p. 16, sonnet 23, lines 13-14; p. 40, sonnet 64, line 14; p. 45, sonnet 76, line 4; p. 60, madrigal 18.

43. E.g. Barnes, Parthenophil, p. 6, sonnet 6; p. 23, sonnet 32; p. 115, canzon 3.

44. Barnes, Parthenophil, p. 38, madrigal 13; p. 45, sonnet 76, line 7.

45. Barnes, Parthenophil, p. 30, sonnet 48.

46. Barnes, Parthenophil, p. 39, sonnet 63.

47. Barnes, Parthenophil, pp. 127-30, sestine 5.

48. Barnes, Parthenophil, p. xxxix.

49. He died aged only 38. Madeleine Hope Dodds, "Barnabe Barnes of Durham: author and playwright," C.H. Hunter Blair, ed., Archaeologia Aeliana or Miscellaneous Tracts Relating to Antiquity (Gateshead: Northumberland Press, 1946), pp. 56-7; Mark Eccles, "Barnabe Barnes," Charles J. Sisson, ed., Thomas Lodge and Other Elizabethans (Cambridge, Mass.: Harvard University Press, 1933), p. 240.

50. Eccles, pp. 170, 240.

51. Barnes, Parthenophil, p. 18, sonnet 28; p. 28, sonnet 44; p. 39, madrigal 14; p. 50, sonnet 87 ; p. 51 , sonnet 89 ; p. 63 , madrigal 24 , line 2 ; pp. $126-7$, ode 20 , lines $10-11$.

52. For speculation as to the possible identity of Parthenophe/Mary, see Eccles, p. 172; Dodds, pp. 11-12; Barnes, Parthenophil, pp. xxii-xxiv.

53. Barnes, Parthenophil, p. 97, ode 3.

54. Barnes, Parthenophil, pp. 97-8, ode 4.

55. Quoted in Aston, p. 319.

56. Arthur Marotti, Religious Ideology and Cultural Fantasy: Catholic and anti-Catholic discourses in early modern England (Notre Dame, Indiana: University of Notre Dame Press, 2005), p. 30.

57. Barnabe Barnes, A Divine Centurie of Spirituall Sonnets (London, 1595), sig. H2r.

58. E.g. Barnes, Divine Centurie, sonnet 73.

59. Barnes, Divine Centurie, sonnets 2, 8, 29. 
60. E.g. Barnes, Divine Centurie, sonnet 23.

61. Nashe, sig. Q2v; Dodds, p. 26.

62. Nashe, sig. Q2v.

63. Dodds, p. 35.

64. Eccles, p. 219.

65. All biographical information from George Wickes, "Henry Constable, Poet and Courtier (1562-1613),” Biographical Studies 1534-1829, vol. II, no. 4 (Bognor Regis: Arundel Press, July 1954), pp. 272-300; and Henry Constable, The Poems of Henry Constable, ed. Joan Grundy (Liverpool: Liverpool University Press, 1960), pp. 21-39.

66. Constable, pp. 84-105; Robert F. Fleissner, Resolved to Love: The 1592 Edition of Henry Constable's "Diana" Critically Considered, Salzburg Studies in English Literature 93 (Salzburg: Universität Salzburg, 1980), pp. ii-iv.

67. Constable, p. 33.

68. Constable, p. 125, sonnet I.ii.4; p. 131, sonnet I.iii.2; p. 135, sonnet I.iii.6. I have chosen to use Grundy's edition since it is the most readily accessible place to find Constable's poems. However, for a critique of her edition and an alternative edition using the 1592 Diana as copy-text rather than manuscript sources, see Fleissner.

69. Constable, p. 133, sonnet I.iii.4.

70. Constable, p. 134, sonnet I.iii.5.

71. Constable, p. 165, sonnet III.i.7.

72. Constable, p. 154, sonnet II.iii.3; p. 155, sonnet II.iii.4; p. 152, sonnet II.iii.1.

73. Constable, p. 174, sonnet III.iii.4.

74. Constable, p. 145, sonnet II.ii.2.

75. Alison Shell, Catholicism, Controversy, and the English Literary Imagination, 15581660 (Cambridge: Cambridge University Press, 1999), p. 124.

76. Constable, p. 137, sonnet II.i.1, line 12.

77. Constable, p. 139, sonnet II.i.2.

78. Articles whereupon it was agreed by the Archbishoppes and Bishoppes... 1562 (London, 1571), p. 14, Article 22.

79. Donne, Elegies and the Songs and Sonnets, p. 11, line 13.

80. Drayton, in Evans ed., p. 108, sonnet 49, line 12.

81. Eamon Duffy, The Stripping of the Altars: Traditional Religion in England c.1400-c.1580 (New Haven and London: Yale University Press, 1992), pp. 338-9, 376, 577-8, 589, 591; Anthony Low, "Hamlet and the ghost of purgatory: intimations of killing the father," English Literary Renaissance 29 (1999), p. 447.

82. William Shakespeare, Hamlet, in Stephen Greenblatt et al., ed., The Norton Shakespeare (New York, London: Norton, 1997), 1.5.10-13.

83. See E.A.J. Honigmann, Shakespeare: The "Lost Years" (Manchester University Press, 1985).

84. Stephen Greenblatt, Hamlet in Purgatory (Princeton, NJ: Princeton University Press, 2001), pp. 236-9; and see Low, passim. 
54/ Renaissance and Reformation / Renaissance et Réforme

85. Constable, p. 185.

86. Constable, p. 189.

87. Constable, p. 190.

88. Constable, p. 189.

89. Constable, p. 190.

90. Constable, pp. 190-91.

91. Constable, pp. 188-9.

92. Constable, p. 192.

93. Marotti, Religious Ideology, p. 101.

94. William Alabaster, Unpublished Works, ed. Dana F. Sutton (Salzburg: University of Salzburg, 1977), p. 130.

95. The Sonnets of William Alabaster, ed. G.M. Story and Helen Gardner (Oxford: Oxford University Press, 1959), p. 38, sonnet 69, "Of the Motions of the Fiend," line 7.

96. Alabaster, p. 34, sonnet 61, "Incarnatio Divini Amoris Argumentum," line 1-3.

97. Alabaster, p. 18, sonnet 34, “Upon the Crucifix (3)," lines 11-13.

98. Alabaster, p. 39, sonnet 71, "The Difference 'twixt Compunction and Cold Devotion in Beholding the Passion of our Saviour," lines 7-8.

99. Marotti, Religious Ideology, p. 204; Michael O'Connell, “The idolatrous eye: iconoclasm, antitheatricalism, and the image of the Elizabethan theater," English Literary History 52 (1985), pp. 279-310.

100. The Poems of Thomas Randolph, ed. G. Thorn-Drury (London: Etchell \& Macdonald, 1929), pp. 66-7.

101. Poems of Thomas Carew, ed. Rhodes Dunlap (Oxford: Clarendon, 1949), pp. 49-53, lines 91-6.

102. J. E. Ruoff, “Thomas Carew's early reputation,” Notes and Queries 202 (1957), pp. 61-2.

103. Edward Thimelby, "Letters to Mr. Normington," Arthur Clifford, ed., Tixall Poetry: With Notes and Illustrations (Edinburgh: Ballantyne, 1813), p. 42. The poem appears in a commonplace book dated 1653. 